$\xi=$

\title{
Influence of temperature and different culture media on growth of fusarium udum (Butler), causal organism of wilt of pigeonpea
}

\author{
Udaysingh Arjun Desai *, Yogesh Suresh Andoji, Shivaji Sopan Kamble \\ Department of Botany, Shivaji University, Kolhapur, India \\ *Corresponding author E-mail: desaiudaysingh@gmail.com
}

\begin{abstract}
The conditions suitable for growth of Fusarium udum causing wilt of Pigeon pea were analysed. Pigeon pea seed agar medium and Czapek Dox Agar medium was found to be most suitable growth medium for mycelial growth and sporulation of Fusarium udum. The optimum temperature for growth of Fusarium udum was found to be $28 \pm 2{ }^{\circ} \mathrm{C}$.
\end{abstract}

Keywords: Pigeon Pea Wilt; Fusarium Udum; Temperature; Culture Media.

\section{Introduction}

Pigeon pea is an important food crop in India. It is a very demanding and always in need food crop in India. India holds a major contribution of $90 \%$ of total world production. India engages an area of 3.85 million hectare with an annual production of 2.68 million tonnes (Anonymous, 2002). The crop is prone to many serious diseases caused by fugal, bacterial viral and nematode infections. High sensitivity of the crop to the attack of insect-pests and diseases appears to be the main reason for such low yields. Pigeonpea is known to be affected by more than hundred pathogens (Nene et al., 1989). However, only a few of them cause economic losses. The diseases of considerable economic importance at present are sterility mosaic (SM), Fusarium wilt, Phytophthora blight (PB), Macrophomina root rot, stem canker and Alternaria blight.

Wilt caused by Fusarium udum Butler is the most important disease caused to this crop (Kannaiyan et al., 1984). Fusarium udum is a soil born pathogen and also the pigeonpea specific wilt pathogen (Kannaiyan et al., 1985). It causes huge loss to the crop as well as economic loss to the farmers. The fungus has an ability to survive in the infected crop debris for $3-4$ years and cause serious economic loss, sometimes upto $100 \%$ in the susceptible cultivars (Kiprop et al., 2002). The loss caused by Fusarium udum in India alone is US \$ 71 million (Reddy et al. 1993). The economic loss caused by Fusarium wilt in Pigeon pea is 470,000 tonnes in India (Joshi et al., 2001). Besides these, the members of the Fusarium have been reported to produce type A and B trichothecene mycotoxins that cause toxicosis in humans and animals (Mali et al., 2015).

\section{Material and methods}

During present investigation, infected plant parts from field were collected and brought to the laboratory. After collection isolation of pathogen was made. To isolate the causal agent, tissue samples were excised from symptomatic leaves, sterilized by sequential dipping in $70 \%$ ethanol for $30 \mathrm{sec}$. and in $0.1 \% \mathrm{HgCl}_{2}$ for $1 \mathrm{~min}$., rinsed in sterilized distilled water, and then cultured on Czapek Dox agar (CDA) amended with $25 \mathrm{mg} /$ litre of streptomycin sulphate to avoid bacterial contamination (Patil et al., 2012). Plates were incubated at $25 \pm 2{ }^{\circ} \mathrm{C}$ for 6 days. A Fusarium sp. was consistently isolated from infected tissues, and was purified by singlespore culture (Mali et al, 2015)*****. The fungus was grown on CDA and cultures were maintained at $4^{\circ} \mathrm{C}$ for further studies. To evaluate the effect of temperature on the radial mycelia growth of pathogen, the cultures plates having $8 \mathrm{~mm}$ diameter mycelial disc of Fusarium udum were incubated at various temperature $0,5,10$, $15,20,25,30,35,35,40^{\circ} \mathrm{C}$.

Different media were selected for the assessment of the growth of the Fusarium udum viz. Pigeon pea root Agar, Pigeon pea stem Agar, Pigeon pea leaf Agar, Pigeon pea seed Agar, Potato Dextrose Agar, Czapek Dox Agar, Sabouraud Agar, Corn meal Agar, Malt Extract Agar. Composition of growth media were listed in (Table 1. a and Table 1. b). The culture media were prepared (Ronald, 2006) by the extract obtained from plant parts of Pigeon pea. In order to investigate the effect of media composition on the growth of pathogen, different media as stated above were tested. Colony diameter was recorded by measuring the radial growth of the mycelium in $\mathrm{mm}$ after eight days of incubation at $28 \pm 2{ }^{\circ} \mathrm{C}$ and number of spores $/ \mathrm{cm}^{3}$ were counted by using Haemocytometer. All the experiments were carried out in triplicates.

Table 1: (A) Composition of Different Fungal Media Containing Host Plant Tissue.

\begin{tabular}{|c|c|c|c|}
\hline $\begin{array}{l}\text { Nutrient Media } \\
\text { Pigeon pea seed } \\
\text { agar }\end{array}$ & $\begin{array}{l}\text { Pigeon pea leaf } \\
\text { agar }\end{array}$ & $\begin{array}{l}\text { Pigeon pea } \\
\text { stem agar }\end{array}$ & $\begin{array}{l}\text { Pigeon pea root } \\
\text { agar }\end{array}$ \\
\hline $\begin{array}{l}\text { Pigeon pea seed } \\
200 \mathrm{~g}\end{array}$ & $\begin{array}{l}\text { Pigeon pea leaf } \\
200 \mathrm{~g}\end{array}$ & $\begin{array}{l}\text { Pigeon pea } \\
\text { stem } \\
200 \mathrm{~g}\end{array}$ & $\begin{array}{l}\text { Pigeon pea root } \\
200 \mathrm{~g}\end{array}$ \\
\hline $\begin{array}{l}\text { Dextrose } 20 \mathrm{~g} \\
\text { Agar } 20 \mathrm{~g} \\
\text { Distilled Water } \\
1000 \mathrm{ml}\end{array}$ & $\begin{array}{l}\text { Dextrose } 20 \mathrm{~g} \\
\text { Agar } 20 \mathrm{~g} \\
\text { Distilled Water } \\
1000 \mathrm{ml}\end{array}$ & $\begin{array}{l}\text { Dextrose } 20 \mathrm{~g} \\
\text { Agar } 20 \mathrm{~g} \\
\text { Distilled Water } \\
1000 \mathrm{ml}\end{array}$ & $\begin{array}{l}\text { Dextrose } 20 \mathrm{~g} \\
\text { Agar } 20 \mathrm{~g} \\
\text { Distilled Water } \\
1000 \mathrm{ml}\end{array}$ \\
\hline
\end{tabular}


Table 1: (B) Czapek Dox Agar (CDA) Media Composition

\begin{tabular}{ll}
\hline Constituents & Concentration $\left(\mathrm{g} \mathrm{L}^{-1}\right)$ \\
\hline NaNO3 & 2.00 \\
$\mathrm{KH} 2 \mathrm{PO} 4$ & 2.00 \\
$\mathrm{MgSO} 4.7 \mathrm{H} 2 \mathrm{O}$ & 0.50 \\
$\mathrm{KCl}$ & 0.50 \\
$\mathrm{FeSO} 4.7 \mathrm{H} 2 \mathrm{O}$ & 0.01 \\
Sucrose & 30.00 \\
Agar- Agar & 20.00 \\
Distilled water & $1000 \mathrm{ml}$ \\
\hline
\end{tabular}

\section{Result and discussion}

In current investigation, the pathogen was exposed to different ranges of temperature (Table no.2). The optimum temperature for the growth and spore production of Fusarium udum in vitro was within range $\left(25-30^{\circ} \mathrm{C}\right)$ (Table no. 2). In the current experiment, it was found that, mycelial growth was reduced at temperature below $15{ }^{\circ} \mathrm{C}$ and above $35^{\circ} \mathrm{C}$ (Figure. 1). Among the different media tested, maximum growth of Fusarium udum was obtained on culture medium containing host plant tissue such as Pigeon pea seed agar followed by Pigeon pea leaf agar, Pigeon pea stem agar, Pigeon pea root agar as compared to Czapek Dox agar medium (Figure. 2). Effect of different culture media on radial growth of Fusarium udum at $28 \pm 2{ }^{\circ} \mathrm{C}$ for 8 days of incubation is shown in Fig no. 3 and Fig. 4 and graphically represented in Fig no. 5 and Fig no. 6.

Table 2: Mycelial Diameter $(\mathrm{Cm})$ and Number of Spores/ $\mathrm{Cm}^{3}$ of Fusarium Udum Cultured on Czapek Dox Agar at Various Temperature.

\begin{tabular}{llll}
\hline Sr. no. & Temperature ${ }^{\circ} \mathrm{C}$ & Radial mycelial growth $(\mathrm{cm})$ & Spores number $/ \mathrm{cm}^{3}$ \\
\hline 1 & 0 & 00 & 0 \\
2 & 5 & 0.5 & 0 \\
3 & 10 & 1 & 8 \\
4 & 15 & 2.7 & 58 \\
5 & 20 & 5 & 122 \\
6 & 25 & 6.6 & 154 \\
7 & 30 & 8.9 & 210 \\
8 & 35 & 2.1 & 34 \\
9 & 40 & 00 & 0 \\
\hline
\end{tabular}

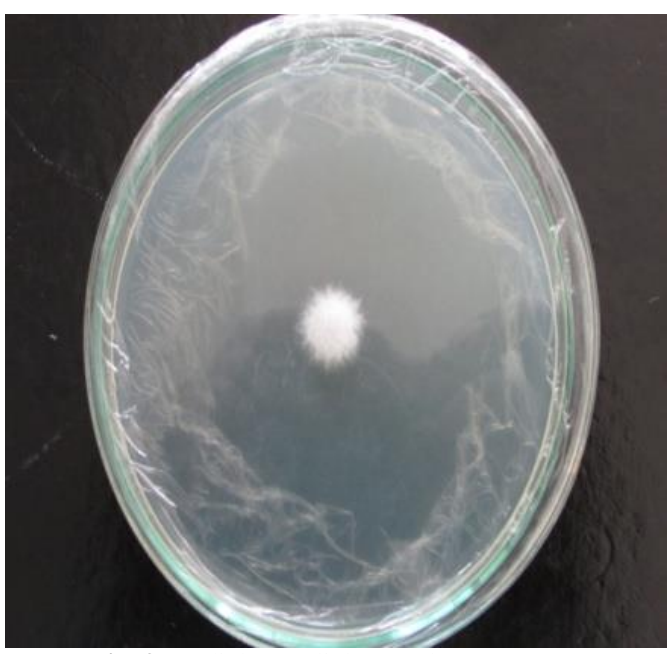

Fig .3: Radial Mycelial Growth at $10 \pm 2^{\circ} \mathrm{C}$.

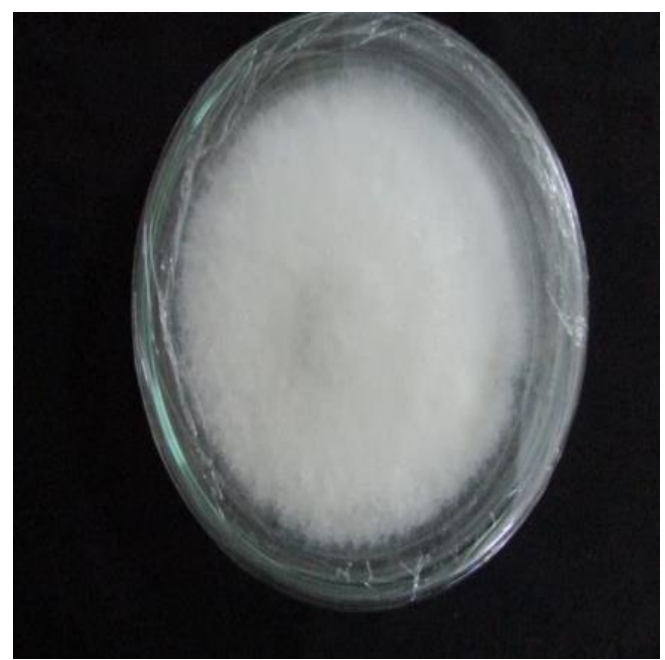

Fig. 4: Radial Mycelial Growth at $28 \pm 2^{\circ} \mathrm{C}$. 


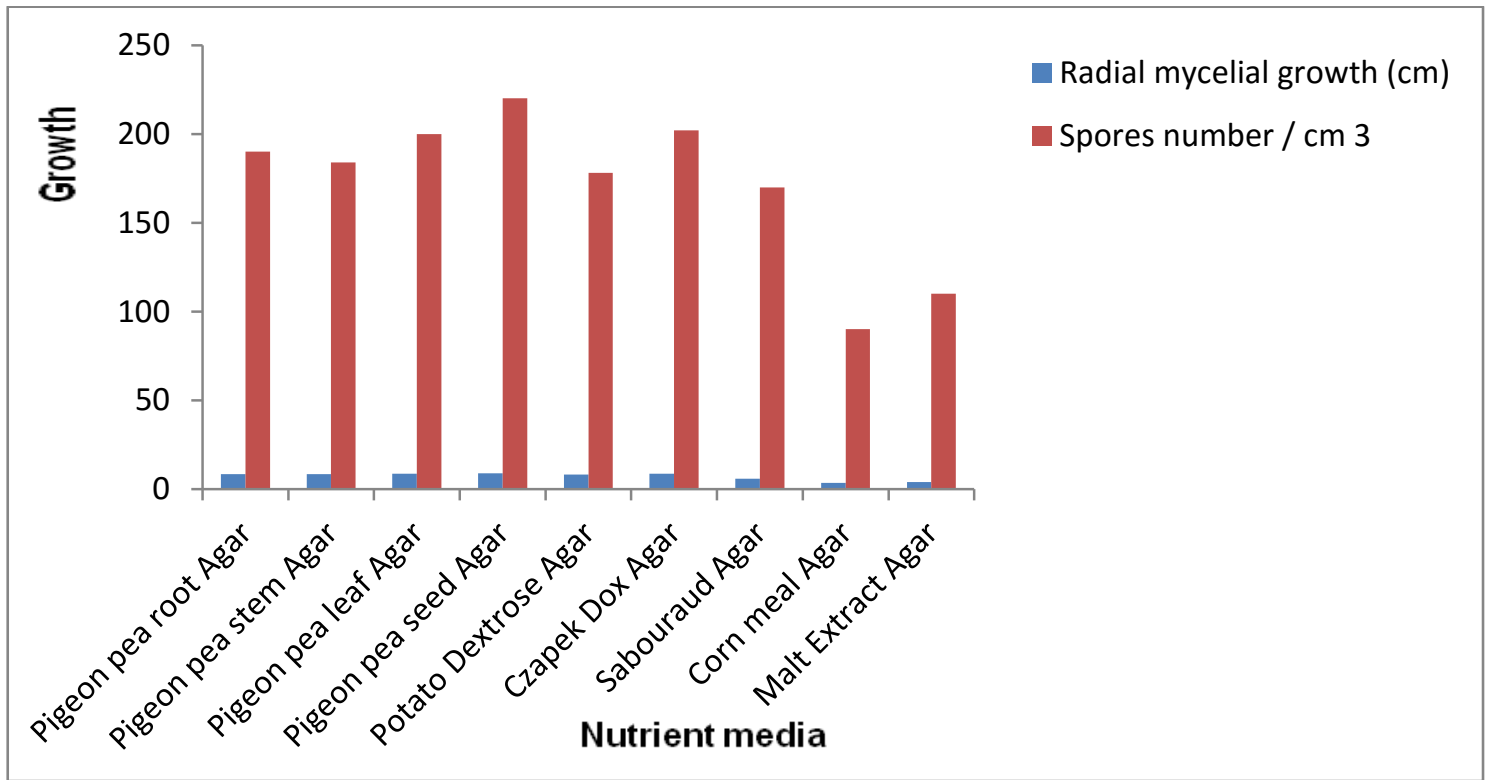

Fig. 5: Effect of Different Culture Media on Radial Growth of Fusarium Udum at $28 \pm 2{ }^{\circ} \mathrm{C}$ for 8 Days of Incubation.
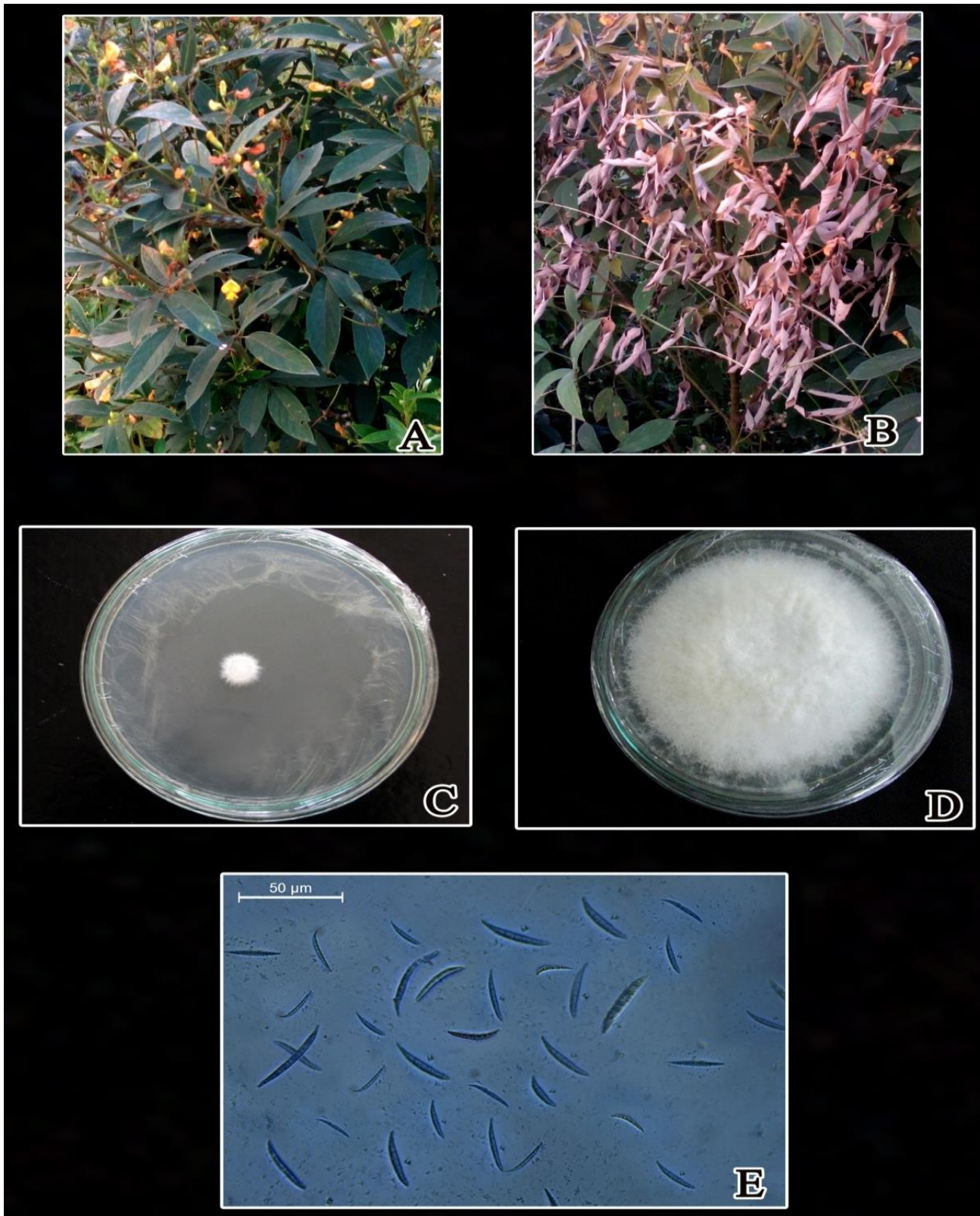

Fig. 6: A-Healthy Plant of Pigeon Pea, B Sympomatic Plant of Pigeon Pea, C - Radial Mycelial Growth at $10 \pm 2{ }^{\circ} \mathrm{C}, \mathrm{D}-\mathrm{Radial}$ Mycelial Growth at $28 \pm$ $2^{\circ} \mathrm{C}$, and $\mathrm{E}-$ Spores of Fusarium Udum. 


\section{Conclusion}

After this investigation it is concluded that Pigeon pea seed agar and Czapek Dox Agar medium are an ideal medium for linear radial growth of Fusarium udum and $28{ }^{\circ} \mathrm{C}$ is the optimum temperature.

\section{Acknowledgement}

We are grateful to the Professor and Head, Department of Botany, Shivaji University, Kolhapur for providing the necessary research facilities.

\section{References}

[1] Anonymous, (2002) Annual Progress Report Of 2001-2002. Indian Institute of Pulse Research (IIPR), Kanpur, India.

[2] Kannaiyan J, Nene Y L and Raju T N (1985) Host Specificity of Pigeonpea Wilt Pathogen Fusarium Udum. Indian Phytopath. 38: 553.

[3] Kiprop E K, Baudoin J P, Mwang'ombe A W, Kimani P M, Mergeai G, Maquet A (2002) Characterization Of Kenyan Isolates Of Fusarium Udum From Pigeonpea [Cajanus Cajan (L.) Millsp.] Cultural Characteristics, Aggressiveness and AFLP Analysis. J. Phytopathol.150:517-527. http://dx.doi.org/10.1046/j.14390434.2002.00798.x.

[4] Reddy M V, Nene Y L, Kannaiyan J, Raju T N, Saka V N, Davor A T, Songa W P And Omanga P (1993) "Pigeonpea Lines Resistant To Wilt In Kenya And Malawi”, International Pigeonpea News Letter, Vol 6, 1990, P. 34

[5] Joshi P K, Parthasarathy Rao P, Gowda C L L, Jones R B, Silim S N, Saxena K B And Kumar J (2001) The World Chickpea And Pigeonpea Economies: Facts, Trends, And Outlook. In: Shiferaw B, Silim S, Muricho G, Audi P, Mligo J, Lyimo S, You L. And Christiansen JL. 2005. Assessment of the Adoption and Impact of Improved Pigeonpea Varieties in Tanzania. Journal of SAT Agricultural Research 3(1).

[6] Rael K, James O, Said N S (2012) Importance And Management Of Fusarium Wilt (Fusarium Udum Butler) Of Pigeonpea. International Journal of Agronomy and Agricultural Research (IJAAR). Vol. 2, No. 1, P. 1-14

[7] Ronald M A. (2006) "Hand Book of Microbiological Media for the Examination of Food," CRC Press. Taylor and Francis Group.

[8] Patil V B, Mali A M, Mahamuni R J, Chavan N S And Kamble S S (2012) First Report Of Leaf Spot Caused By Phoma Costarricensis On Delphinium Malabaricum In Western Ghats Of India. Plant Disease. 96:1074. 10.1094/PDIS-12-11-1012-PDN. http://dx.doi.org/10.1094/PDIS-12-11-1012-PDN

[9] Mali A M, Patil V B, Ade A B, Chavan N S And Kamble S S (2015) First Report Of Fusarium Sp. FIESC_17 On Cucumis Trigonus In India. Plant Disease. 10.1094/PDIS-09-14-0881-PDN. http://dx.doi.org/10.1094/PDIS-09-14-0881-PDN

[10] Kannaiyan J, Nene Y L, Reddy M V, Ryan J G and Raju T N (1984) Prevalence of Pigeonpea Diseases and Associated Crop Losses in Asia, Africa and America. Tropical Pest Management 30: 62-71 http://dx.doi.org/10.1080/09670878409370853.

[11] Nene Y L, Sheila V K And Sharma S B (1989) A World List Of Chickpea And Pigeonpea Pathogens. Legume Pathology Progress Report, 7: 23.

[12] Anonymous. (2006) Annual Report for 2006-07. In: ICAR Network Project On Wilt Of Crops With Special Reference To Cultural, Morphological, Molecular Characterization And Pathogenic Variability Of Isolates In India, IIPR, Kanpur, $210 \mathrm{Pp}$. 